\title{
Sexualized Drug Use Among Female Sex Workers from Eight Cities in China: A Cross-Sectional Study
}

\author{
Jason J. Ong ${ }^{1} \cdot$ Mingzhou Xiong ${ }^{2,3} \cdot$ Joseph D. Tucker ${ }^{4} \cdot$ Yajie Wang $^{2,3} \cdot$ M. Kumi Smith ${ }^{5} \cdot$ Weiming Tang $^{2} \cdot$ Hongyun Fu $^{6}$. \\ Heping Zheng ${ }^{2,3} \cdot$ Bin Yang $^{2,3} \cdot$ Cheng Wang ${ }^{2,3}$ (-)
}

Received: 9 January 2021 / Revised: 26 July 2021 / Accepted: 26 July 2021 / Published online: 16 November 2021

(c) The Author(s) 2021

\begin{abstract}
There is a rich literature on sexualized drug use (i.e., drug use before or during sex) for men who have sex with men but less data from female sex workers (FSW), particularly from low- and middle-income countries. We describe the sexual and reproductive health outcomes in FSW reporting sexualized drug use. In 2019, we conducted a cross-sectional study in eight cities from seven provinces in China. We recruited FSW through community organizations working with sex workers and included those aged 18 years or above, exchanged sex at least once for money or goods in the past three months, and had traded sex for longer than a year. Multivariable logistic regression models were used. In total, 650 women participated: average age was 38.8 years (SD 10.2), 57.1\% reported a monthly income over 5000 RMB (\$USD 707), and $12.8 \%$ completed high school or above. Among participants, 65 (10.0\%, 95\% confidence interval (CI) 7.8-12.6) reported a history of sexualized drug use. Compared to FSW who never reported a history of sexualized drug use, FSW who reported a history of sexualized drug use had greater odds of working for a manager compared to being self-employed (adjusted odds ratio (AOR) 4.04, 95\% CI 2.12-7.69), work in a sauna (AOR 2.43, 95\% CI 1.09-5.41), charging a higher price for vaginal sex (AOR 2.15, 95\% CI 1.14-4.06), and ever diagnosed with STIs (AOR 4.51, 95\% CI 2.61-7.80). One in ten FSW reported sexualized drug use. Although they had similar risk profiles in terms of consistency of condom use and reproductive health outcomes, these women were more likely to report past STIs than those who reported no sexualized drug use. Health workers who work with substance users should devote attention to the sexual practices of their clients to make sure that they have safer sex.
\end{abstract}

Keywords HIV $\cdot$ Female sex workers $\cdot$ Sexualized drug use

Cheng Wang

wangcheng090705@gmail.com

1 Central Clinical School, Monash University, Melbourne, VIC, Australia

2 Dermatology Hospital of Southern Medical University, No. 2 Lujing Road, Yuexiu District, Guangzhou 510095, China

3 Southern Medical University Institute for Global Health and Sexually Transmitted Diseases, Guangzhou, Guangdong, China

4 Faculty of Infectious and Tropical Diseases, London School of Hygiene and Tropical Medicine, London, UK

5 Division of Epidemiology and Community Health, University of Minnesota, Twin Cities, MN, USA

6 Division of Community Health and Research, Eastern Virginia Medical School, Norfolk, VA, USA

\section{Introduction}

Female sex workers (FSW) are vulnerable to social and cultural marginalization, stigma and discrimination, socioeconomic disadvantage, and human right abuses (UNAIDS, 2014). This has been further exacerbated during the COVID19 pandemic (UNAIDS, 2020). FSW are often at higher risk of acquiring HIV/sexually transmitted infections (STIs) than the rest of the population (Baral et al., 2012; Zhang et al., 2020). This elevated risk for acquiring HIV/STIs is exacerbated by the use of illicit drugs, particularly when multiple layers of stigma exist related to sex work, illicit drugs, and STIs (Whitaker et al., 2011). However, public health authorities often overlook this challenging aspect of disease prevention in FSW - illicit drug use. Drug dependence may lead to entry into sex work, used to cope with challenges associated with sex work or as a means to purchase drugs (Gossop et al., 1995; Syvertsen et al., 2019; Ulibarri et al., 2013). Illicit 
drug use among FSW is associated with mental health issues (such as depression), increased frequency of condomless sex, acquisition of HIV/STIs, unintended pregnancy, violence, and coercive sex (Chen et al., 2013; Church et al., 2001; Luchters et al., 2016; Pandiyan et al., 2012; Semple et al., 2016). Additionally, injecting drug use may increase the risk of acquiring HIV and other blood-borne infections (such as hepatitis C) among FSW (Nguyen et al., 2004; Tran et al., 2005).

Although there is some research about recreational drug use before or during sex-referred to here as sexualized drug use-in FSW living in low- and middle-income countries (Li et al., 2014; Loza et al., 2010; Morris et al., 2011; Parry et al., 2009; Shannon et al., 2008; Strathdee et al., 2008; Syvertsen et al., 2019), it is not clear whether FSW who report sexualized drug use may also be at elevated risk for acquiring HIV/STIs; this is in contrast to the rich literature on sexualized drug use for men who have sex with men (Bourne et al., 2018). Regarding sexualized drug use among FSW, studies from the US-Mexican border report sexualized drug use among FSW ranged from 14 to 63\% (Loza et al., 2010; Morris et al., 2011; Strathdee et al., 2008). A study of 198 survival sex workers in Canada reported that 59\% shared drugs with clients in the preceding six months and that sexualized drug use was associated with inconsistent condom use, verbal harassment, physical and/or sexual assault (Shannon et al., 2008). A qualitative study of Kenyan FSW reported how drugs enabled these women to undertake sex work-'sex work was intolerable when sober' (Syvertsen et al., 2019). A study from China reported reasons for sexualized drug use related to client request or the opportunity to make more money (Li et al., 2014). Another study from drug using commercial sex workers ( $71 \%$ females) living in South Africa reported that drugs were used to enhance the sexual experience and prolong sex and may be associated with inconsistent condom use (Parry et al., 2009). Together, these studies highlight the need to understand better how sexualized drug use impacts the health of FSW, especially in contexts (like China) where punitive environments exist for both sex work and drug use, meaning that FSW who engage in sexualized drug use might be at an even greater disadvantage. Drug users and sex workers in China can be detained for up to 15 days. According to the Anti-Drug Law of the People's Republic of China, drug users can be fined up to 2000 RMB (about 300 US dollars), and individuals may be sent to a drug rehabilitation center for up to 2 years. According to the Law of the People's Republic of China on Public Security Administration Penalties, sex workers can be fined up to $5000 \mathrm{RMB}$ (about 750 US dollars) depending on the severity of the case.

The Syndemic Model of Health suggests that there may be a clustering of harmful health behaviors due to synergistic interactions between diseases and their social context (Singer et al., 2017). Therefore, FSW reporting sexualized drug use may be more likely to report other harmful health outcomes. Our study aims to contribute to the data of sexualized drug use among FSW in low- and middle-income countries by describing the sociodemographic characteristics, sexual behaviors, and HIV/STI testing behaviors among FSW reporting sexualized drug use. We hypothesized that disaggregating data by sexualized drug use provides valuable insights into their unique health challenges. Specifically, FSW who reported a history of sexualized drug use would have a different risk profile than FSW who reported no sexualized drug use.

\section{Method}

\section{Participants}

This cross-sectional study, led by a provincial STI Control Center, was implemented in eight cities (Beijing, Tianjin, Shenzhen, Kunming, Jiaozhou, Yunfu, Xiangyang and Longnan) within seven provinces in China between August 17 and October 17, 2019. We collaborated with eight communitybased organizations (CBOs) in these cities with experience in conducting female sex workers outreach programs (Appendix 1). Eligible participants were aged 18 years or above; exchanged sex (vaginal, oral, and/or anal) at least once for money or goods in the past three months; and willing to participate in the survey by providing verbal inform consent. We restricted the study's analysis to participants who traded sex for more than a year to capture data from more established workers.

\section{Procedure}

The Wenjuanxing platform (Changsha Haoxing Information Technology Co., Ltd., China) was used to create an online survey link that allowed participants to complete the survey by smartphone or computer tablets. The survey was created by the research group and revised by local CBO stakeholders, policymakers, and international HIV/STI experts. Following a pilot study among $50 \mathrm{FSWs}$, the survey procedures were adjusted to simplify administration and improve survey comprehensibility. The primary outcome of this study was sexualized drug use among FSW.

The outreach workers of the CBOs recruited FSW using convenience sampling from a variety of workplaces of FSWs: hair salons, saunas, bath centers, karaoke bars, dancing hall bars, sidewalk snack vendors, hotels, nightclubs, massage parlors, guesthouses, and public outdoor places. Interested participants clicked on a survey link that assessed their eligibility, and the research system (Wenjuanxing) verified the uniqueness of the mobile phone number to avoid participants giving multiple entries. Phone numbers of participants were not available to the researchers. Each survey was 
self-administered by the eligible participant on their device at the recruitment site; they could ask the $\mathrm{CBO}$ worker for help if needed.

\section{Measures}

We asked about sexualized drug use through the question: "Have you ever used the following substances before or during sex" (none, heroin, cocaine, crack, methamphetamine, speedball (heroin plus cocaine), other opioids, solvents/ glue, hallucinogens, marijuana, other). The survey also asked about: (1) sociodemographic characteristics (age, marital status, monthly income, education level, source of sample, household registration, and migration status); (2) Sexual behaviors (employment status for commercial sex, duration of commercial sex, number of clients served in the past month, average amount received for vaginal sex with a client, consistency of condom use with vaginal sex in the past month, condom use at last vaginal sex, consistency of condom use with oral sex in the past month, consistency of condom use with anal sex in the past month, ever had an unintended pregnancy, ever had an abortion and current contraception method); and (3) HIV/STI testing behaviors (ever had an HIV test, result of last HIV test, ever had syphilis test, result of last syphilis test, ever diagnosed with STIs).

\section{Statistical Analysis}

Data were downloaded from the Wenjuanxing platform and analyzed using IBM SPSS ${ }^{\circledR}$ version 24.0. Descriptive statistics were used to summarize the characteristics of the study sample. $\chi^{2}$ test or Fisher's exact test (for categorical variables), and $t$ test or Wilcoxon rank-sum test (for continuous variables) were used to identify statistically significant differences in sexual and reproductive health behaviors and outcomes among different groups of FSWs by background characteristics. Multivariable logistic regression models were used to explore the associations between sexualized drug use and sexual behavioral and HIV/STI testing behavioral factors. Based on our literature review, we adjusted for the potential confounders of injecting drug use in the preceding six months (a known risk factor for adverse health outcomes for FSW), age, marital status, migration status, income, and education in each of the models.

\section{Results}

\section{Sociodemographic Characteristics (Table 1)}

Overall, their average age was 38.8 years (standard deviation (SD) 10.2 ), a significant proportion was married (44.9\%), about half reported a monthly income over 5000 RMB (US\$
$707,57.1 \%$ ) and a minority completed high school or above (17.4\%, Table 1). FSWs were recruited from a variety of venues: foot-washing rooms/hair salons (40.3\%), saunas (13.7\%), karaoke/dancing hall/bars (15.9\%), street (15.1\%), and other venues (15.1\%). Most reported a rural household registration $(74.2 \%$, an official record of the person's residential origin), and only a minority were current residents (22.6\%).

There were significant differences for sociodemographic variables comparing those who reported a history of sexualized drug use with those who reported no sexualized drug use. Compared to FSW who reported no sexualized drug use, those who reported a history of sexualized drug use were more likely to be younger, married, less monthly income, higher education level, work in a sauna or karaoke bar, have a rural household registration and local residents.

Among 650 participants, 65 (10.0\%, 95\% CI 7.8-12.6) reported a history of sexualized drug use. Methamphetamine was most commonly used before or during sex $(n=24)$, followed by marijuana $(n=16)$, hallucinogens $(n=12)$, heroin $(n=10)$, and cocaine $(n=8)$. Another 21 participants also reported other drug use beyond our list. Among these 21 participants, six used Rush, four used cough syrup, three used ecstasy, two used ketamine, and one used flunitrazepam, three did not know what drug they took, and two participants did not specify the "other" drug.

\section{Sex Work Parameters (Table 2)}

The majority of FSWs were self-employed (58.0\%). A minority of women consistently used condoms with clients in the past month for vaginal sex (42.5\%), oral sex (15.5\%), and anal sex (3.6\%). Most reported an unintended pregnancy (64.6\%) or had at least one abortion (66.3\%), and only one out of four women were using a long-acting reversible contraceptive $(27.6 \%)$.

Compared to FSW who reported no sexualized drug use, FSW who reported a history of sexualized drug use were more likely to work for a manager, served fewer clients, received more money for vaginal sex, more likely to have an unintended pregnancy and abortion, and less likely to use long-acting reversible contraception.

\section{HIV/STI Testing Behaviors (Table 3)}

The majority of FSW reported ever testing for HIV (93.4\%), and $1.9 \%$ reported living with HIV. A lower majority reported ever testing for syphilis (84.8\%), and $13.7 \%$ reported a positive syphilis result with their last test. A minority of FSW (23.9\%) reported ever being diagnosed with an STI (including herpes, chlamydia, gonorrhea, warts, and hepatitis). Compared to FSW who reported no sexualized drug use, FSW who reported a history of sexualized drug use were less 
Table 1 Comparison of the sociodemographic characteristics of female sex workers in China, 2019 $(N=650)$

\begin{tabular}{|c|c|c|c|c|}
\hline Characteristics & $\begin{array}{l}\text { Sexualized drug use } \\
n(\%)\end{array}$ & $\begin{array}{l}\text { No sexualized } \\
\text { drug use } \\
n(\%)\end{array}$ & $p$ value & $\begin{array}{l}\text { Total } \\
n(\%)\end{array}$ \\
\hline Total & $65(10.0)$ & $585(90.0)$ & & \\
\hline \multicolumn{5}{|l|}{ Age (years) } \\
\hline Mean \pm SD & $33.9 \pm 8.2$ & $39.3 \pm 10.3$ & $<.001$ & $38.8 \pm 10.2$ \\
\hline Marriage & & & .001 & \\
\hline Never married and not cohabiting & $7(10.8)$ & $57(9.7)$ & & $64(9.9)$ \\
\hline Never married but cohabiting & $9(13.9)$ & $59(10.1)$ & & $68(10.5)$ \\
\hline Married & $41(63.1)$ & $251(42.9)$ & & $292(44.9)$ \\
\hline Divorced or widowed & $8(12.3)$ & $218(37.3)$ & & $226(34.8)$ \\
\hline Monthly income ${ }^{\mathrm{a}}$ & & & .07 & \\
\hline less than 3000 RMB (\$USD 424) & $6(9.2)$ & $76(13.0)$ & & $82(12.6)$ \\
\hline 3001-5000 RMB (\$USD 425-707) & $27(41.5)$ & $170(29.1)$ & & $197(30.3)$ \\
\hline 5001-8000 RMB (\$USD 708-1131) & $18(27.7)$ & $136(23.3)$ & & $154(23.7)$ \\
\hline Over 8000 RMB (over \$USD 1131) & $14(21.5)$ & $203(34.7)$ & & $217(33.4)$ \\
\hline Education & & & .03 & \\
\hline Elementary school or below & $27(41.5)$ & $260(44.4)$ & & $287(44.1)$ \\
\hline Junior high school & $23(35.4)$ & $257(43.9)$ & & $280(43.1)$ \\
\hline High school or above & $15(23.1)$ & $68(11.6)$ & & $83(12.8)$ \\
\hline Source of sample & & & .001 & \\
\hline Foot-washing room/hair salon & $18(27.7)$ & $244(41.7)$ & & $262(40.3)$ \\
\hline Sauna/bath center & $17(26.2)$ & $72(12.3)$ & & $89(13.7)$ \\
\hline Karaoke/dancing Hall/bar & $16(24.6)$ & $87(14.9)$ & & $103(15.9)$ \\
\hline Street & $3(4.6)$ & $95(16.2)$ & & $98(15.1)$ \\
\hline Others $^{\mathrm{b}}$ & $11(16.9)$ & $87(14.9)$ & & $98(15.1)$ \\
\hline Household registration & & & .89 & \\
\hline Rural & $48(73.9)$ & $434(74.2)$ & & $482(74.2)$ \\
\hline Urban & $17(26.2)$ & $149(25.5)$ & & $166(25.5)$ \\
\hline I am not sure & $0(0)$ & $2(0.3)$ & & $2(0.3)$ \\
\hline Migration status & & & $<.001$ & \\
\hline Local residents & $35(53.9)$ & $112(19.2)$ & & $147(22.6)$ \\
\hline Another city of this province & $18(27.7)$ & $146(25.0)$ & & $164(25.2)$ \\
\hline Another province & $12(18.5)$ & $327(55.9)$ & & $339(52.2)$ \\
\hline
\end{tabular}

$\mathrm{RMB}=$ renminbi or Chinese yuan, $1 \mathrm{RMB}=0.14$ US dollar; $\mathrm{SD}=$ standard deviation; USD $=$ US dollar

${ }^{a}$ This relates to the overall personal monthly income of the individual and is not restricted to income from commercial sex work. An average worker in China earns approximately \$376 USD per month (Chinese National Bureau of Statistics: National Bureau of Statistics. Personal income and consumer spending in 2019 2020. http://www.stats.gov.cn/tjsj/zxfb/202001/t20200117_1723396.html. Accessed 22-April-2021)

${ }^{\mathrm{b}}$ Others include sidewalk snack vendor/diner, hotel, nightclub, massage parlor, call girl, online advertising likely to be living with HIV but more likely to be diagnosed with an STI in the past.

Table 4 summarizes the regression analyses of FSW. Compared to FSW who never reported any sexualized drug use, FSW who reported a history of sexualized drug use had greater odds of working for a manager, working in a sauna, received more money for vaginal sex and ever diagnosed with STIs in the past.

\section{Discussion}

This study of $650 \mathrm{FSW}$ from eight Chinese cities reveals that a history of sexualized drug use identified FSW who had greater associations with adverse sexual and reproductive health outcomes, even after accounting for injecting drug use (a known risk factor for adverse health outcomes in FSW). While much has been published about the associations 
Table 2 Comparison of the sexual behavioral characteristics of female sex workers in China, $2019(N=650)$

\begin{tabular}{|c|c|c|c|c|}
\hline Characteristics & $\begin{array}{l}\text { Sexualized drug use } \\
n(\%)\end{array}$ & $\begin{array}{l}\text { No sexualized } \\
\text { drug use } \\
n(\%)\end{array}$ & $p$ value ${ }^{\mathrm{a}}$ & $\begin{array}{l}\text { Total } \\
n(\%)\end{array}$ \\
\hline Total & $65(10.0)$ & $585(90.0)$ & & \\
\hline Employment status & & & $<.001$ & \\
\hline Self-employed/freelance FSW & $16(24.6)$ & $361(61.7)$ & & $377(58.0)$ \\
\hline Work for a manager & $48(73.9)$ & $216(36.9)$ & & $264(40.6)$ \\
\hline Other & $1(1.5)$ & $8(1.4)$ & & $9(1.4)$ \\
\hline Clients served in the past month & & & .05 & \\
\hline$\leq 22$ (cutoff is the median) & $37(56.9)$ & $257(43.9)$ & & $294(45.2)$ \\
\hline$>22$ & $28(43.1)$ & $328(56.1)$ & & $356(54.8)$ \\
\hline Average amount received per vaginal sex act (USD) & & & $<.001$ & \\
\hline$\leq 21$ (cutoff is median) & $23(35.4)$ & $353(60.3)$ & & $376(57.9)$ \\
\hline$>21$ & $42(64.6)$ & $232(39.7)$ & & $274(42.2)$ \\
\hline Consistency of condom use with vaginal sex in the past month ${ }^{\mathrm{a}}$ & & & .49 & \\
\hline Not always used & $40(61.5)$ & $334(57.1)$ & & $374(57.5)$ \\
\hline Always used & $25(38.5)$ & $251(42.9)$ & & $276(42.5)$ \\
\hline Consistency of condom use with oral sex in the past month ${ }^{\mathrm{a}}$ & & & .10 & \\
\hline Not always used & $33(94.3)$ & $306(83.6)$ & & $339(84.5)$ \\
\hline Always used & $2(5.7)$ & $60(16.4)$ & & $62(15.5)$ \\
\hline Consistency of condom use with anal sex in the past month ${ }^{\mathrm{a}}$ & & & .07 & \\
\hline Not always used & $5(83.3)$ & $49(98.0)$ & & $54(96.4)$ \\
\hline Always used & $1(16.7)$ & $1(2.0)$ & & $2(3.6)$ \\
\hline Ever had an unintended pregnancy & & & $<.001$ & \\
\hline None & $18(27.7)$ & $212(36.2)$ & & $230(35.4)$ \\
\hline 1 time & $20(30.8)$ & 169 (28.9) & & $189(29.1)$ \\
\hline $2-3$ times & $12(18.5)$ & $173(29.6)$ & & $185(28.5)$ \\
\hline 4-5 times & $11(16.9)$ & $25(4.3)$ & & $36(5.5)$ \\
\hline Over 5 times & $4(6.2)$ & $6(1.0)$ & & $10(1.5)$ \\
\hline Ever had abortion & & & $<.001$ & \\
\hline None & $16(24.6)$ & $203(34.7)$ & & $219(33.7)$ \\
\hline 1 time & $17(26.2)$ & $190(32.5)$ & & $207(31.9)$ \\
\hline $2-3$ times & $17(26.2)$ & $170(29.1)$ & & $187(28.8)$ \\
\hline 4-5 times & $13(20.0)$ & $16(2.7)$ & & $29(4.5)$ \\
\hline Over 5 times & $2(3.1)$ & $6(1.0)$ & & $8(1.2)$ \\
\hline \multicolumn{5}{|l|}{ Current contraception method } \\
\hline Male condom & $46(73.0)$ & $425(75.0)$ & .74 & $471(74.8)$ \\
\hline Female condom & $18(27.7)$ & $97(16.6)$ & .03 & $115(18.3)$ \\
\hline Oral contraceptive & $19(30.2)$ & $142(25.0)$ & .38 & $161(25.6)$ \\
\hline IUD/injectables/patches & $7(11.1)$ & $167(29.5)$ & $<.01$ & $174(27.6)$ \\
\hline Spermicide & $0(0)$ & $45(7.9)$ & .01 & $45(7.1)$ \\
\hline Traditional methods (e.g., safety period calculation, herbal tea) & $3(4.8)$ & $21(3.7)$ & .68 & $24(3.8)$ \\
\hline
\end{tabular}

IUD = intrauterine device; USD = US dollar

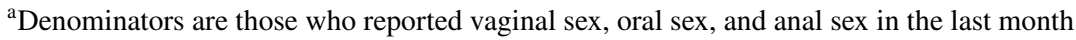

between injecting drug use and adverse sexual and reproductive health outcomes (Cepeda et al., 2015; Hail-Jares et al., 2016; Lau et al., 2012; Lau et al., 2007; Le et al., 2016; Li et al., 2014; Liao et al., 2016; McDougal et al., 2013; Medhi et al., 2012; Odinokova et al., 2014; Yao et al., 2012; Zhang et al., 2014), our study provides data on sexualized drug use (independent of injecting drug use) among FSW.

The self-report of sexualized drug use among FSW compounded their risks for sexual and reproductive health outcomes compared to their non-drug using peers. It is already 
Table 3 Comparison of the HIV/STI testing behaviors of female sex workers in China, $2019(N=650)$

\begin{tabular}{|c|c|c|c|c|}
\hline Characteristics & $\begin{array}{l}\text { Sexualized drug use } \\
n(\%)\end{array}$ & $\begin{array}{l}\text { No sexualized } \\
\text { drug use } \\
n(\%)\end{array}$ & $p$ value & $\begin{array}{l}\text { Total } \\
n(\%)\end{array}$ \\
\hline Total & $65(10.0)$ & $585(90.0)$ & & \\
\hline Ever had an HIV test & & & .16 & \\
\hline Yes & $58(89.2)$ & $549(93.9)$ & & $607(93.4)$ \\
\hline No & $7(10.8)$ & $36(6.2)$ & & $43(6.6)$ \\
\hline Result of last HIV test ${ }^{\mathrm{a}}$ & & & .03 & \\
\hline Positive & $0(0.0)$ & $12(2.1)$ & & $12(1.9)$ \\
\hline Negative & $56(86.2)$ & $535(91.5)$ & & $591(90.9)$ \\
\hline Indeterminate & $1(1.5)$ & $0(0)$ & & $1(0.2)$ \\
\hline I don't know & $1(1.5)$ & $2(0.3)$ & & $3(0.5)$ \\
\hline Ever had syphilis test & & & .69 & \\
\hline Yes & $54(83.1)$ & $497(85.0)$ & & $551(84.8)$ \\
\hline No & $11(16.9)$ & $88(15.0)$ & & $99(15.2)$ \\
\hline Result of last syphilis test & & & .41 & \\
\hline Positive & $5(7.7)$ & $84(14.4)$ & & 89 (13.7) \\
\hline Negative & 48 (73.9) & $405(69.2)$ & & $453(69.7)$ \\
\hline Indeterminate & $0(0)$ & $4(0.7)$ & & $4(0.6)$ \\
\hline I don't know & $1(1.5)$ & $4(0.7)$ & & $5(0.8)$ \\
\hline Ever diagnosed with STIs ${ }^{\mathrm{b}}$ & & & $<.001$ & \\
\hline Yes & $35(53.9)$ & $120(20.5)$ & & $155(23.9)$ \\
\hline No & $30(46.2)$ & 465 (79.5) & & $495(76.2)$ \\
\hline
\end{tabular}

established that injecting drug use among FSW is associated with increased risks of STIs (Cepeda et al., 2015; Hail-Jares et al., 2016; Li et al., 2014; Liao et al., 2016; Medhi et al., 2012; Yao et al., 2012), HIV (Le et al., 2016; Li et al., 2014; Yao et al., 2012), higher unintended pregnancy rates (Li et al., 2014), reproductive morbidity (McDougal et al., 2013), less consistent condom use (Lau et al., 2007, 2012; Li et al., 2014), violence (McDougal et al., 2013; Odinokova et al., 2014; Zhang et al., 2014), and mental health problems (Zhang et al., 2014). We add to this literature by demonstrating a history of sexualized drug use is also associated with adverse sexual and reproductive health outcomes. Our disaggregated data of FSW reporting sexualized drug use uncovered significant differences in sociodemographic characteristics, sexual behaviors, and HIV/STI testing behaviors compared with their non-drug using peers. This emphasizes the need to measure sexualized drug use among FSW as an additional risk factor for adverse health outcomes and thus direct additional resources to them such as empowerment-based harm reduction programs (Hawk et al., 2017) or strength-based interventions (Surratt et al., 2014). In China, methadone maintenance clinics, needle exchange programs, drug use counseling, and voluntary drug rehabilitation centers are available in major cities.
We also found that compared to FSW who never reported any sexualized drug use, FSW who reported a history of sexualized drug use had greater odds of working for a manager, working in a sauna, and received more money for vaginal sex. There are complex reasons for sexualized drug use, which could pull or push FSW into using drugs. For instance, a study from Chinese FSW found that client request and monetary incentives were reasons for drug use with clients ( $\mathrm{Li}$ et al., 2014). This is similar to experiences of FSW from other countries where FSW earned money to sustain their drug habit (Syvertsen et al., 2014) or directly exchange sex for crack (cocaine) (Duff et al., 2013). It is possible that working for a manager or working in a sauna may facilitate the use of sexualized drug use but as this was a cross-sectional study, we were unable to determine the direction of causality. Further qualitative research will be needed to understand this association with the greater likelihood of sexualized drug use.

The main strength of our study is acquiring data from a large number of FSW working in diverse locations, with varying durations of time working in the sex industry. Our data, disaggregated by sexualized drug use, are a unique contribution to the current literature on FSW and highlight 
Table 4 Factors related to sexualized drug use among female sex workers in China, $2019(N=650)$

\begin{tabular}{|c|c|c|c|c|}
\hline Variables & $\begin{array}{l}\text { Sexualized drug use } \\
\text { Crude OR } \\
(95 \% \text { CI })\end{array}$ & $p$ value & $\begin{array}{l}\text { Sexualized drug use } \\
\text { Adjusted OR }{ }^{\mathrm{a}} \\
(95 \% \mathrm{CI})\end{array}$ & $p$ value \\
\hline \multicolumn{5}{|c|}{ Employment status for commercial sex work } \\
\hline Self-employed & Ref & & Ref & \\
\hline For a manager & $5.01(2.78-9.05)$ & $<.001$ & $4.04(2.12-7.69)$ & $<.001$ \\
\hline \multicolumn{5}{|l|}{ Source of work } \\
\hline $\begin{array}{l}\text { Foot-washing room/ } \\
\text { hair salon }\end{array}$ & Ref & & Ref & \\
\hline Sauna & $3.20(1.57-6.53)$ & .001 & $2.43(1.09-5.41)$ & .030 \\
\hline Karaoke/bar & $2.49(1.22-5.10)$ & .012 & $1.79(0.82-3.90)$ & .141 \\
\hline Street & $0.42(0.12-1.49)$ & .182 & $0.41(0.12-1.43)$ & .162 \\
\hline Other & $1.71(0.78-3.77)$ & .181 & $1.55(0.69-3.50)$ & .289 \\
\hline \multicolumn{5}{|c|}{ Average price for vaginal sex (USD) } \\
\hline$\leq 21$ & Ref & & Ref & \\
\hline$>21$ & $2.78(1.63-4.74)$ & $<.001$ & $2.15(1.14-4.06)$ & .018 \\
\hline \multicolumn{5}{|c|}{ Current long-acting reversible contraception } \\
\hline No & Ref & & Ref & \\
\hline Yes & $0.30(0.14-0.68)$ & $<.001$ & $0.49(0.21-1.15)$ & .100 \\
\hline \multicolumn{5}{|c|}{ Ever diagnosed with STIs } \\
\hline No & Ref & & & \\
\hline Yes & $4.52(2.67-7.66)$ & $<.001$ & $4.51(2.61-7.80)$ & $<.001$ \\
\hline
\end{tabular}

$\mathrm{OR}=$ odds ratio Ref $=$ Reference level $; \mathrm{USD}=$ United States Dollar; 95\% CI $=95 \%$ confidence interval

${ }^{a}$ Adjusted for each variable in the table, as well as injecting drug use, age, marital status, migration status, income, and education the unique challenges faced by a distinct group of sexualized drug-using FSW. Our findings should be read in light of several limitations. Although we attempted to recruit a representative sample of FSW working in diverse settings, this was not a random sample. There is a risk of social desirability bias as we relied on self-report of drug use, consistent with other studies regarding drug use. We tried to mitigate this bias by the anonymous nature of the survey. Our survey question related to drug use during or before sex was not specific for sexualized drug use during commercial sex, nor was it able to determine the pattern of use (e.g., only at the entry into sex work or throughout). Therefore, our findings of the association with adverse health outcomes related to women reporting ever experiencing sexualized drug use (regardless of whether this was in the context of commercial sex work or not, and the pattern of sexualized drug use). We did not include questions regarding alcohol use before or during sex, which may also increase the risk of HIV/STIs in FSW (Wang et al., 2010). Given the brief nature of the survey, we did not ask about how drug use affected women's lives, and we could not distinguish between non-problematic and problematic drug use. More research is needed to explore the drug-related harms of sexualized drug use for FSW. We did not differentiate between the experiences of FSW who received money from those who received goods for delivering sexual health services. Finally, we did not include males or transgender sex workers who may have an even higher risk for HIV/STIs. This will be the subject of future research.

\section{Conclusion}

Our study highlights the sexual and reproductive health needs of FSW with a history of sexualized drug use. Similar to guidelines regarding sexualized drug use among MSM (Clutterbuck et al., 2018), we recommend additional supports for FSW who report sexualized drug use to mitigate the associations with other adverse sexual and reproductive health outcomes. Additional supports may include greater access to drug counseling, methadone maintenance programs, needle exchange programs, drug rehabilitation services, and compassionate care by health care providers. Similarly, health workers who work with substance users should devote some attention to the sexual practices of their clients to make sure that they have safer sex. 


\section{Appendix 1}

\begin{tabular}{|c|c|c|c|c|c|c|c|c|c|}
\hline Name of institution & $\begin{array}{l}\text { Number of } \\
\text { FSW served } \\
\text { in } 2018\end{array}$ & $\begin{array}{l}\text { Official } \\
\text { coopera- } \\
\text { tion with } \\
\text { Govern- } \\
\text { ment/ } \\
\text { CDC/ } \\
\text { Hospital }\end{array}$ & $\begin{array}{l}\text { Primary services provided } \\
\text { to FSW }\end{array}$ & City & $\begin{array}{l}\text { Region of } \\
\text { China }\end{array}$ & $\begin{array}{l}\text { Population } \\
\text { of the city }\end{array}$ & $\begin{array}{l}\text { GPD per } \\
\text { capita (USD) }\end{array}$ & $\begin{array}{l}\text { Type of } \\
\text { city }\end{array}$ & Ethnic breakdown \\
\hline $\begin{array}{l}\text { Beijing Firefly } \\
\text { Women Group }\end{array}$ & 700 & Yes & $\begin{array}{l}\text { 1. HIV/STD test and treat- } \\
\text { ment promotion } \\
\text { 2. High-risk sex behavior } \\
\text { intervention }\end{array}$ & Beijing & Northern & $\begin{array}{l}21.54 \text { mil- } \\
\text { lion }\end{array}$ & $24 \mathrm{k}$ & 1 st tier & $\begin{array}{l}\text { Han }(95.69 \%), \text { Man- } \\
\text { chu, Hui, Mongo- } \\
\text { lian, Korean, etc. } \\
56 \text { ethnics }\end{array}$ \\
\hline $\begin{array}{l}\text { Tianjin Sunflower } \\
\text { Migrant Women } \\
\text { Service Center }\end{array}$ & 3000 & Yes & $\begin{array}{l}\text { 1. Training skills on repro- } \\
\text { ductive health and HIV/ } \\
\text { STD prevention } \\
\text { 2. Provide HIV/STD testing } \\
\text { 3. Provide HIV/syphilis } \\
\text { self-test kit }\end{array}$ & Tianjin & Northern & $\begin{array}{l}15.62 \text { mil- } \\
\quad \text { lion }\end{array}$ & $17 \mathrm{k}$ & 1 st tier & $\begin{array}{l}\text { Han }(97 \%) \text {, Hui } \\
\text { (2\%), Manchu } \\
(0.6 \%), \text { Mongo- } \\
\text { lian, Korean, etc. } \\
52 \text { ethnics }\end{array}$ \\
\hline $\begin{array}{l}\text { Xiangyang Ziwei } \\
\text { Garden Health } \\
\text { Consulting Studio }\end{array}$ & 1200 & Yes & $\begin{array}{l}\text { 1. Training skills on repro- } \\
\text { ductive health and HIV/ } \\
\text { STD prevention } \\
\text { 2. Provide HIV/STD testing } \\
\text { 3. Provide HIV/syphilis } \\
\text { self-test kit } \\
\text { 4. Community empower- } \\
\text { ment }\end{array}$ & Xiangyang & Central South & 6.05 million & $11 \mathrm{k}$ & 3rd tier & $\begin{array}{l}\text { Han }(99.6 \%) \text {, Hui } \\
\quad(0.4 \%)\end{array}$ \\
\hline $\begin{array}{l}\text { Shenzhen Hongci } \\
\text { Women Care } \\
\text { Service Center }\end{array}$ & 5000 & Yes & $\begin{array}{l}\text { 1. Training skills on repro- } \\
\text { ductive health and HIV/ } \\
\text { STD prevention } \\
\text { 2. Provide HIV/STD testing } \\
\text { 3. STD linkage to care }\end{array}$ & Shenzhen & Southern & $\begin{array}{l}13.44 \text { mil- } \\
\text { lion }\end{array}$ & $29.5 \mathrm{k}$ & 1 st tier & $\begin{array}{l}\text { Han, Zhuang, Tujia, } \\
\text { Miao, Dong, etc. } \\
56 \text { ethnics ( } 7.8 \%)\end{array}$ \\
\hline $\begin{array}{l}\text { Yunfu Zhongyue } \\
\text { AIDS Care Res- } \\
\text { cue Center }\end{array}$ & 600 & Yes & $\begin{array}{l}\text { 1. High-risk sex behavior } \\
\text { intervention } \\
\text { 2. Provide psychological } \\
\text { support } \\
\text { 3. HIV/syphilis/NG consult- } \\
\text { ing and test }\end{array}$ & Yunfu & Southern & 2.55 million & $4.7 \mathrm{k}$ & 4th tier & $\begin{array}{l}99.6 \% \text { Han, with } \\
0.4 \% \text { minority } \\
\text { ethnicity }\end{array}$ \\
\hline $\begin{array}{l}\text { Kunming Parallel } \\
\text { Sexual Health } \\
\text { Support and } \\
\text { Development } \\
\text { Center }\end{array}$ & 1200 & Yes & $\begin{array}{l}\text { High-risk sex behavior } \\
\text { intervention } \\
\text { 2. Provide HIV/STD testing }\end{array}$ & Kunming & Southwest & 6.95 million & $10.6 \mathrm{k}$ & 2nd tier & $\begin{array}{l}\text { Han }(86.16 \%) \text {, } \\
\quad \text { minority ethnics } \\
\quad(13.84 \%)\end{array}$ \\
\hline $\begin{array}{l}\text { Longnan Longjiang } \\
\text { Support Group }\end{array}$ & 1940 & Yes & $\begin{array}{l}\text { 1. Provide a platform for } \\
\text { FSW to get HIV/syphilis/ } \\
\text { HCV test }\end{array}$ & Longnan & Northwest & 2.64 million & $2.2 \mathrm{k}$ & 5 th tier & $\begin{array}{l}\text { Han }(97.69 \%), \\
\text { minority ethnics } \\
(2.31 \%)\end{array}$ \\
\hline $\begin{array}{l}\text { Jiaozhou Love } \\
\text { Health Service } \\
\text { Center }\end{array}$ & 2000 & Yes & $\begin{array}{l}\text { 1. High-risk sex behavior } \\
\text { intervention } \\
\text { 2. Gynecological examina- } \\
\text { tion } \\
\text { 3. Provide HIV/STD testing } \\
\text { 4. Training skills on repro- } \\
\text { ductive health and HIV/ } \\
\text { STD prevention }\end{array}$ & Jiaozhou & Eastern & 0.91 million & $18 \mathrm{k}$ & 4th tier & $\begin{array}{c}\text { Han }(99.3 \%) \text {, minor- } \\
\text { ity ethnics }(0.7 \%)\end{array}$ \\
\hline
\end{tabular}


Acknowledgements We acknowledge the time and contribution of all study participants.

Authors' contribution Jason J. Ong and Mingzhou Xiong are equal first authors. CW designed the project. CW, MX, YW, WT, HZ, and BY conducted the study. JJO, JDT, MS, and HF provided technical and modeling advice throughout the project and critically revised the manuscript. All authors participated in the interpretation of results and critically revised the manuscript. All authors reviewed the manuscript and approved the final version.

Funding This study has been funded by the Dermatology Hospital of Southern Medical University (2019017). JJO is funded by an Australian National Health and Medical Research Council Fellowship (GNT1104781).

Availability of data and materials All data generated or analyzed during this study are included in this published article. Additional information may be requested from the corresponding author.

\section{Declarations}

Conflict of interest All authors declare no competing interests.

Ethical Approval This study was approved by the Dermatology Hospital of Southern Medical University (2019017).

Informed consent Verbal informed consent was obtained from all the participants who agreed to participate in this study.

Open Access This article is licensed under a Creative Commons Attribution 4.0 International License, which permits use, sharing, adaptation, distribution and reproduction in any medium or format, as long as you give appropriate credit to the original author(s) and the source, provide a link to the Creative Commons licence, and indicate if changes were made. The images or other third party material in this article are included in the article's Creative Commons licence, unless indicated otherwise in a credit line to the material. If material is not included in the article's Creative Commons licence and your intended use is not permitted by statutory regulation or exceeds the permitted use, you will need to obtain permission directly from the copyright holder. To view a copy of this licence, visit http://creativecommons.org/licenses/by/4.0/.

\section{References}

Baral, S., Beyrer, C., Muessig, K., Poteat, T., Wirtz, A. L., Decker, M. R., Decker, M. R., \& Kerrigan, D. (2012). Burden of HIV among female sex workers in low-income and middle-income countries: A systematic review and meta-analysis. The Lancet Infectious Diseases, 12(7), 538-549. https://doi.org/10.1016/S1473-3099(12)70066-X

Bourne, A., Ong, J., \& Pakianathan, M. (2018). Sharing solutions for a reasoned and evidence-based response: Chemsex/party and play among gay and bisexual men. Sexual Health, 15(2), 99-101. https://doi.org/10.1071/SH18023

Cepeda, A., Nowotny, K. M., \& Valdez, A. (2015). Injecting drug use among mexican female sex workers on the US-Mexico border. Journal of Ethnicity in Substance Abuse, 14(4), 351-363. https:// doi.org/10.1080/15332640.2014.991467

Chen, Y., Li, X., Shen, Z., Zhou, Y., \& Tang, Z. (2013). Alcohol and sexual risk: An event-level analysis in commercial sex setting.
Addictive Behaviors, 38(12), 2888-2892. https://doi.org/10.1016/j. addbeh.2013.08.019

Church, S., Henderson, M., Barnard, M., \& Hart, G. (2001). Violence by clients towards female prostitutes in different work settings: Questionnaire survey. BMJ, 322(7285), 524-525. https://doi.org/ 10.1136/bmj.322.7285.524

Clutterbuck, D., Asboe, D., Barber, T., Emerson, C., Field, N., Gibson, S., Gibson, S., \& Sullivan, A. (2018). 2016 United Kingdom national guideline on the sexual health care of men who have sex with men. International Journal of STD and AIDS. https://doi.org/ 10.1177/0956462417746897

Duff, P., Tyndall, M., Buxton, J., Zhang, R., Kerr, T., \& Shannon, K. (2013). Sex-for-Crack exchanges: Associations with risky sexual and drug use niches in an urban Canadian city. Harm Reduction Journal, 10, 29. https://doi.org/10.1186/1477-7517-10-29

Gossop, M., Powis, B., Griffiths, P., \& Strang, J. (1995). Female prostitutes in south London: Use of heroin, cocaine and alcohol, and their relationship to health risk behaviours. AIDS Care, 7(3), 253-260. https://doi.org/10.1080/09540129550126498

Hail-Jares, K., Choi, S., Duo, L., Luo, Z., \& Huang, Z. J. (2016). Occupational and demographic factors associated with drug use among female sex workers at the China-Myanmar border. Drug and Alcohol Dependence, 161, 42-49. https://doi.org/10.1016/j.drugalcdep. 2016.01.026

Hawk, M., Coulter, R. W. S., Egan, J. E., Fisk, S., Reuel Friedman, M., Tula, M., \& Kinsky, S. (2017). Harm reduction principles for healthcare settings. Harm Reduction Journal, 14(1), 70. https:// doi.org/10.1186/s12954-017-0196-4

Lau, J. T., Gu, J., Tsui, H. Y., Chen, H., Holroyd, E., Wang, R., \& Hu, X. (2012). Prevalence and associated factors of condom use during commercial sex by female sex workers who were or were not injecting drug users in China. Sexual Health, 9(4), 368-376. https://doi. org/10.1071/SH11108

Lau, J. T., Zhang, J., Zhang, L., Wang, N., Cheng, F., Zhang, Y., Zhang, Y., \& Lan, Y. (2007). Comparing prevalence of condom use among 15,379 female sex workers injecting or not injecting drugs in China. Sexually Transmitted Diseases, 34(11), 908-916. https:// doi.org/10.1097/OLQ.0b013e3180e904b4

Le, T. T., Nguyen, Q. C., Tran, H. T., Schwandt, M., \& Lim, H. J. (2016). Correlates of HIV infection among street-based and venue-based sex workers in Vietnam. International Journal of STD and AIDS, 27(12), 1093-1103. https://doi.org/10.1177/0956462415608556

Li, Z., Li, D., Jiang, Z., Liu, H., \& Wang, N. (2014). [A study on syphilis and HSV-2 infection and related behaviors among female sex workers who take new types of drugs in Jiaozhou city]. Zhonghua Yu Fang Yi Xue Za Zhi, 48(10), 857-861. Retrieved from https:// www.ncbi.nlm.nih.gov/pubmed/25573122

Liao, M., Su, S., Yan, K., Zhu, X., Huang, P., Li, J., Li, J., \& Zhao, J. (2016). Dual epidemics of drug use and syphilis among Chinese female sex workers: Results of eight consecutive cross-sectional surveys from 2006 to 2013 in Qingdao, China. AIDS and Behavior, 20(3), 655-666. https://doi.org/10.1007/s10461-015-1229-1

Loza, O., Patterson, T. L., Rusch, M., Martinez, G. A., Lozada, R., Staines-Orozco, H., Staines-Orozco, H., \& Proyecto Mujer, S. (2010). Drug-related behaviors independently associated with syphilis infection among female sex workers in two Mexico-US border cities. Addiction, 105(8), 1448-1456. https://doi.org/10. 1111/j.1360-0443.2010.02985.x

Luchters, S., Bosire, W., Feng, A., Richter, M. L., King'ola, N., Ampt, F., Ampt, F., \& Chersich, M. F. (2016). "A baby was an added burden": Predictors and consequences of unintended pregnancies for female sex workers in Mombasa, Kenya: A mixed-methods study. PLoS ONE, 11(9), e0162871. https://doi.org/10.1371/journ al.pone. 0162871 
McDougal, L., Strathdee, S. A., Rangel, G., Martinez, G., Vera, A., Sirotin, N., Sirotin, N., \& Raj, A. (2013). Adverse pregnancy outcomes and sexual violence among female sex workers who inject drugs on the United States-Mexico border. Violence and Victims, 28(3), 496-512. https://doi.org/10.1891/0886-6708.11-00129

Medhi, G. K., Mahanta, J., Kermode, M., Paranjape, R. S., Adhikary, R., Phukan, S. K., \& Ngully, P. (2012). Factors associated with history of drug use among female sex workers (FSW) in a high HIV prevalence state of India. BMC Public Health, 12, 273. https://doi. org/10.1186/1471-2458-12-273

Morris, M. D., Case, P., Robertson, A. M., Lozada, R., Vera, A., Clapp, J. D., Clapp, J. D., \& Strathdee, S. A. (2011). Prevalence and correlates of "agua celeste" use among female sex workers who inject drugs in Ciudad Juarez, Mexico. Drug and Alcohol Dependence, 117(2-3), 219-225. https://doi.org/10.1016/j.drugalcdep.2011.02.007

Nguyen, A. T., Nguyen, T. H., Pham, K. C., Le, T. G., Bui, D. T., Hoang, T. L., Hoang, T. L., \& Detels, R. (2004). Intravenous drug use among street-based sex workers: A high-risk behavior for HIV transmission. Sexually Transmitted Diseases, 31(1), 15-19. https:// doi.org/10.1097/01.OLQ.0000105002.34902.B5

Odinokova, V., Rusakova, M., Urada, L. A., Silverman, J. G., \& Raj, A. (2014). Police sexual coercion and its association with risky sex work and substance use behaviors among female sex workers in St. Petersburg and Orenburg, Russia. International Journal of Drug Policy, 25(1), 96-104. https://doi.org/10.1016/j.drugpo. 2013.06.008

Pandiyan, K., Chandrasekhar, H., \& Madhusudhan, S. (2012). Psychological morbidity among female commercial sex workers with alcohol and drug abuse. Indian Journal of Psychiatry, 54(4), 349-351. https://doi.org/10.4103/0019-5545.104822

Parry, C. D., Dewing, S., Petersen, P., Carney, T., Needle, R., Kroeger, K., \& Treger, L. (2009). Rapid assessment of HIV risk behavior in drug using sex workers in three cities in South Africa. AIDS and Behavior, 13(5), 849-859. https://doi.org/10.1007/ s10461-008-9367-3

Semple, S. J., Pitpitan, E. V., Chavarin, C. V., Strathdee, S. A., Zavala, R. I., Aarons, G. A., \& Patterson, T. L. (2016). Prevalence and correlates of hazardous drinking among female sex workers in 13 Mexican cities. Alcohol and Alcoholism, 51(4), 450-456. https:// doi.org/10.1093/alcalc/agv124

Shannon, K., Kerr, T., Bright, V., Gibson, K., \& Tyndall, M. W. (2008). Drug sharing with clients as a risk marker for increased violence and sexual and drug-related harms among survival sex workers. AIDS Care, 20(2), 228-234. https://doi.org/10.1080/0954012070 1561270

Singer, M., Bulled, N., Ostrach, B., \& Mendenhall, E. (2017). Syndemics and the biosocial conception of health. Lancet, 389(10072), 941-950. https://doi.org/10.1016/S0140-6736(17)30003-X

Strathdee, S. A., Philbin, M. M., Semple, S. J., Pu, M., Orozovich, P., Martinez, G., ..., Patterson, T. L. (2008). Correlates of injection drug use among female sex workers in two Mexico-U.S. border cities. Drug and Alcohol Dependence, 92(1-3), 132-140. https:// doi.org/10.1016/j.drugalcdep.2007.07.001

Surratt, H. L., O’Grady, C., Kurtz, S. P., Levi-Minzi, M. A., \& Chen, M. (2014). Outcomes of a behavioral intervention to reduce HIV risk among drug-involved female sex workers. AIDS and Behavior, 18(4), 726-739. https://doi.org/10.1007/s10461-014-0723-1

Syvertsen, J. L., Agot, K., Ohaga, S., \& Bazzi, A. R. (2019). You can't do this job when you are sober: Heroin use among female sex workers and the need for comprehensive drug treatment programming in Kenya. Drug and Alcohol Dependence, 194, 495-499. https:// doi.org/10.1016/j.drugalcdep.2018.10.019

Syvertsen, J. L., Robertson, A. M., Strathdee, S. A., Martinez, G., Rangel, M. G., \& Wagner, K. D. (2014). Rethinking risk: Gender and injection drug-related HIV risk among female sex workers and their non-commercial partners along the Mexico-U.S. border. International Journal of Drug Policy, 25(5), 836-844. https://doi. org/10.1016/j.drugpo.2014.02.005

Tran, T. N., Detels, R., Long, H. T., \& Lan, H. P. (2005). Drug use among female sex workers in Hanoi, Vietnam. Addiction, 100(5), 619-625. https://doi.org/10.1111/j.1360-0443.2005.01055.x

Ulibarri, M. D., Hiller, S. P., Lozada, R., Rangel, M. G., Stockman, J. K., Silverman, J. G., \& Ojeda, V. D. (2013). Prevalence and characteristics of abuse experiences and depression symptoms among injection drug-using female sex workers in Mexico. Journal of Environmental and Public Health, 2013, 631479. https://doi.org/ $10.1155 / 2013 / 631479$

UNAIDS. (2020). COVID-19 responses must uphold and protect the human rights of sex workers. Retrieved from https://www.unaids. org/en/resources/presscentre/featurestories/2020/april/20200424_ sex-work

UNAIDS. (2014). The Gap Report. Retrieved from https://www.unaids. org/en/resources/documents/2014/20140716_UNAIDS_gap_ report

Wang, B., Li, X., Stanton, B., Zhang, L., \& Fang, X. (2010). Alcohol use, unprotected sex, and sexually transmitted infections among female sex workers in China. Sexually Transmitted Diseases, 37(10), 629-636. https://doi.org/10.1097/OLQ.0b013e3181 e2118a

Whitaker, T., Ryan, P., \& Cox, G. (2011). Stigmatization among drugusing sex workers accessing support services in Dublin. Qualitative Health Research, 21(8), 1086-1100. https://doi.org/10.1177/ 1049732311404031

Yao, Y., Yang, F., Chu, J., Siame, G., Lim, H. J., Jin, X., Jin, X., \& Wang, N. (2012). Associations between drug use and risk behaviours for HIV and sexually transmitted infections among female sex workers in Yunnan, China. International Journal of STD AIDS, 23(10), 698-703. https://doi.org/10.1258/ijsa.2012.011346

Zhang, C., Li, X., Chen, Y., Hong, Y., Shan, Q., Liu, W., \& Zhou, Y. (2014). Alcohol and other drug use, partner violence, and mental health problems among female sex workers in southwest China. Health Care for Women International, 35(1), 60-73. https://doi. org/10.1080/07399332.2012.757317

Zhang, H., Hsieh, E., Wang, L., \& Liao, S. (2020). HIV/AIDS among female sex workers in China: Epidemiology and recent prevention strategies. Current HIV/AIDS Reports, 17(2), 151-160. https://doi. org/10.1007/s11904-019-00477-y

Publisher's Note Springer Nature remains neutral with regard to jurisdictional claims in published maps and institutional affiliations. 